\title{
Featuring the e-service quality of online website from a varied perspective
}

\author{
Huan-Ming Chuang ${ }^{1}$, You-Shyang Chen ${ }^{2 *}$, Chyuan-Yuh Lin ${ }^{1}$ and Pei-Chih Yu ${ }^{1}$
}

\author{
${ }^{*}$ Correspondence: \\ ys_chen@cc.hwh.edu.tw \\ ${ }^{2}$ Department of Information \\ Management, Hwa Hsia \\ University of Technology, 111, \\ Gong Jhuan Road., Chung Ho \\ District, New Taipei City 235, \\ Taiwan, ROC \\ Full list of author information \\ is available at the end of the \\ article
}

\begin{abstract}
The websites vigorously grow and inevitably need to provide consumers high-quality service to create excellent experience and win the customers' heart to establish mutually beneficial and long-term relationship. Consequently, the e-service quality attracts priority-concerns. The research purpose differentiates three service quality models that make the effects on consumer loyalty-related behavior under e-service environment. Data were surveyed from online consumers to test the research model. Conclusively, the empirical results indicate: (1) service quality (SERVQUAL) model appears superior to quality of electronic service (QES) model and website performance index (WPI) model in explaining e-service quality; (2) service quality has significant positive effects on affective, continuance, and normative commitment; (3) affective commitment has significant positive effects on loyalty and advocacy intention; (4) normative commitment has significant effects on loyalty, advocacy intentions, and willingness to pay more; while continuance commitment does not have the same effects.
\end{abstract}

Keywords: Service quality, SERVQUAL, Quality of Electronic Services (QES), Website performance index (WPI)

\section{Background}

Due to rapid development of information technology in recent years, the Internet has not only changed people's way of life but also impacted business activities. According to Business Week reports, Taiwan's online shopping market growth rate in 2009-2011 remained at a high 30.37, 15, and $13.75 \%$. In 2011, Taiwan's online shopping market exceeds $\$ 13.3$ billion, and it is far higher than all the national department stores $\$ 9$ billion, convenience store $\$ 8.1$ billion, and supermarkets $\$ 4.76$ billion. In 2013, the Internet shopping market has exceeded $\$ 16.6$ billion. This information means that the steady growth of online shopping has become the focus of corporate concerns. The rapid rise of e-service is subverting the traditional business model and changing the shopping habits of consumers. Consumers can purchase products through online shopping in addition to physical retail stores; however, the homogeneity of products sold on the Internet causes the threat of price war. As a result, online seller has to establish and maintain long-term partnerships with their customers to create sustainable competitive advantages, and e-service has great potentiality to meet this goal. Therefore, enterprises should pay great attention on the improvement of service quality for their customers. Based on

(c) 2016 Chuang et al. This article is distributed under the terms of the Creative Commons Attribution 4.0 International License (http://creativecommons.org/licenses/by/4.0/), which permits unrestricted use, distribution, and reproduction in any medium, provided you give appropriate credit to the original author(s) and the source, provide a link to the Creative Commons license, and indicate if changes were made. 
the literature [53], service quality will affect consumers' purchase intention greatly, and Zeithaml, Berry and Parasuraman [52] indicated good service quality will produce customers' behavioral intentions. Zhou et al. [53] also pointed out that service quality is the main factor that influences consumer trust and satisfaction to the website. Given the highly competitive and rapidly changing environment, the Internet retailer increasingly emphasizes on service quality; not only for competitive weapon but also for survive.

In the past few decades, academicians and practitioners continually concern service quality. Various researches propose different perspectives and measurement methods with a lot of controversy. Up to now, scholars still don't have high consensus on this issue. It is noteworthy to differentiate Brady and Cronin Jr. [8] perspective of "how" and "what" as well as the gap analysis of service quality (SERVQUAL) model and quality of electronic service (QES) model. First, Brady and Cronin Jr. [8] explored QES with the perspective of "what"; it is believed that the environmental quality, the interaction quality, and the result quality allow the enterprises to know "what" dimension shall be measured during the service quality assessment. On the other hand, Brady and Cronin Jr. [8] explored SERVQUAL through the "how" perspective" pointing out "how" to measure the five dimensions of service quality; in other words, the enterprise can understand how the customers classify the service performance by using these five dimensions. This research adopts a variety of perspectives proposed by Brady and Cronin Jr. [8] on using "how" to review SERVQUAL and "what" for QES as to assess the service quality of the e-business. In addition, Jeon [33] studied the impact of web service on customers' loyalty and developed an instrument fo measuring website performance as Website Performance Index (WPI). In summary, SERVQUAL, QES, and WPI represent three major methods for measuring service quality and worth further comparisons. This study thus focuses on comparing explanation ability of these models; to clarify and suggest appropriate method for interested parties. The study also examines the impact of the mutual relationship between service quality and customer loyalty-related intentions and other factors by using an empirical case study. Finally, research results can promote website managers' understanding of important factors for assessing service quality for consumers, and suggest strategies for e-stores to establish and maintain long-term relationships with their consumers to create sustainable competitive advantages.

\section{Literature review}

\section{Service quality}

Unlike general physical goods, services has four characteristics: Intangibility, heterogeneity, cannot be stored, and indivisible. Although the four characteristics are difficult to define and measure for making service quality, there are three representative methods of measuring service quality in the past studies, as follows.

\section{SERVQUAL}

SERVQUAL, proposed by Parasuraman, Zeithaml, and Berry [43], has been a good and widely used means for measuring service quality. The core of the SERVQUAL is the disconfirmation paradigm, which is the dissonance generated when the perceived service quality differs from the one expected by customers. When the received service quality surpasses the customers' expectation, they will consider they have received high service 
quality; on the contrary, when the received service quality is worse than their expectation, the customers will consider that they have received bad service quality.

In order to avoid overlaps among dimensions, the aforementioned ten service quality dimensions were simplified into five dimensions: Reliability, responsiveness, assurance, empathy, and tangible, which are well-known as the SERVQUAL [44]. The consumers use the following five dimensions to assess the dissonance between the actual service quality and the expected service quality. In other words, the consumers have certain expectations about service owing to words of mouth, personal demands, or past experiences; the five dimensions are applied to compare the service expectations prior to consumption and the actually service provided and obtained as the final result of service quality.

\section{Quality of electronic services (QES)}

Fassnacht and Koese [17] used the three main dimensions-environment quality, process quality, and outcome quality - to develop a hierarchical model for the measurement of online service quality. The environment quality refers to the appearance of the user interface; the process quality (or the delivery quality) refers to the interaction of the consumers with the website during the service process (such as searching information and selecting the product); and the outcome quality refers to the measurement of the service result after accepting the service [17]. Fenglin and Zaixin [18] proposed that e-store service quality is constructed by the three following components: Environment quality, delivery quality, and outcome quality [18]. Moreover, Yi and Gong [51] adjusted the variables to measure the impact of the three components on the overall online service quality with consumers' self-efficacy, which would then influence the customer's satisfaction degree and loyalty [51]. The results show that the outcome quality is the most influential for the overall online service quality followed by delivery of the quality and the environment quality.

\section{Website performance index (WPI)}

Within the online shopping environment, the key indicator to measure the online service quality is through assessing the performance of the website. Dickinger and Stangl [16] pointed out the eight elements of the website performance: System availability, ease of use, usefulness, navigational challenge, website design, content quality, enjoyment, and trust. (1) System availability: It mainly refers to the technological functions and the performance of the website; that is, the information technology applied by the website can provide the users with a good browser environment; users can also leave the un-responding or slow-loading website as soon as possible. (2) Ease of use: The users can easily use the website. (3) Usefulness: The website can provide useful information to the users. (4) Navigational challenge: The overall structure of the website is clear so that the users can navigate the website with ease. (5)Website design: It mainly refers to the external design of the website, including the color combination, the font and style, the pictures, audios, sound, etc. (6) Content quality: The website can provide accurate and practical product information. (7) Enjoyment: It mainly refers to the interactive pleasures between the users and the website. (8) Trust: The 
website can provide a sense of safety to the users so that they will be willing to come back again.

Summarizing the above literature review, this study aims to explore the impact of SERVQUAL, QES, and WPI over the online service quality. The three different measurement methods would be further analyzed and compared to find out the best measurement model. Table 1 aggregately shows the compilation of the above three models.

\section{Commitment}

The concept of commitment is introduced by marketing scholars and extended to the market field, and it can be traced back to organizational behavior, the loyal relationship between the employees and the organization. Commitment is a compulsory element in marketing. Allen and Meyer [1], an organizational behavior scholar, believed that different motivations would cause different commitments in the marketing field. Commitment has therefore threefold: Affective, continuance, and normative commitment [1].

\section{Affective commitment}

Within the marketing field, the concept of affective commitment meaning that one party keeps a business relationship because they like their business partner and enjoy the partnership. Affective commitment can also be considered as a psychological status. Consumers are connected with business partners through psychological acceptance and attachment [24]. Sharma et al. [48] mentioned that with the passing of time, consumers hope to develop and fortify interpersonal relationships to achieve familiarity, friendship, and personal confidence [48]. Overall, affective commitment originates from pleasurable purchase experience or outstanding services, so positive fellings are generated, and consumers maintain the linkage with their partners.

Table 1 Service quality model compilation

\begin{tabular}{lll}
\hline Model & Construct & Definition \\
\hline SERVQUAL & Reliability & Shopping site offers reliability and the ability to service commitments \\
& Responsiveness & Shopping site is willing to help customers and provide prompt service \\
& Assurance & Shopping site offers security and privacy of transactions capabilities \\
Empathy & Shopping site cares and attends to the ability of customers \\
Tangible & Interface design and architecture of shopping site \\
Environment quality & The appearance of the user interface \\
QES & Interaction between the customer and the website during the service \\
& Outcome quality & Consumers measure of service outcome after receiving the service \\
System availability & Website's technical function and performance \\
Ease of use & Users can easily use the site \\
Usefulness & Website can provide useful information \\
Navigational challenge & Overall navigation structure of the site allows users to easily navigate \\
Website design & The external design of the website \\
Content quality & Website can provide accurate and useful product information \\
Enjoyment & The interactive pleasures between the users and the website \\
Trust & Website gives users a sense of security and trust worthy
\end{tabular}




\section{Continuance commitment}

Johnson et al. [34] considered that the generation of the continuance commitment owes to the high conversion cost, lack of replacement, and high dependence. Thus, it is a commitment generated after the calculation of costs and benefits. When consumers consider that ending the economic cost and the social cost as well as the lack of choice to end the relationship with the partner is too much, the continuance commitment will continue to be generated [23]. It is believed that owing to the limitation of the partnership, the relationship is kept via negative motivations [25]. Even though the partner is trying to establish a positive cooperation, consumers would still be limited by the relationship and not being able to leave [20]. In short, when a continuance commitment is generated, consumers would keep the relationship with the partner, yet upon the termination of the cooperation, a bigger price shall be paid.

\section{Normative commitment}

Studies related to normative commitment is relatively few when compared to affective commitment and continuance commitment in the marketing field in the past researches. Customers believe that they have the obligation to do business with the partner so the partnership shall be kept between them [4]. The main reason of keeping the relationship is because customers believe that obtained benefits are based on the principle of reciprocity [12]. Customers have to commit to the partner, a feedback generated for the partner that would eventually generate the ethics and obligation within the customers' minds to keep the partnership. Thus, normative commitment is the psychological linkage generated with the partner that allows customers to keep the relationship.

\section{Behavioral intention}

This study aims to discuss behavioral intention, including the loyalty intention, the advocacy intention, and the willingness to pay more among the consumers after having traded transactions with the e-retailers.

\section{Loyalty intention}

Reviewing the related literature, scholars have explained loyalty through different perspectives of behavior and attitude, so various definitions had been generated. However, it is not possible to fully analyze customer loyalty by discussing solely the attitude or the behavior of the customers. Srinivasan et al. [49] stated that loyalty comes from the adoring attitudes of customers towards shopping websites; thus, customers repeat their purchasing behavior and the intention to visit and repurchase at a website is once again and continued in the future [13].

Furthermore, such a concept is applicable to e-business [46] : when e-loyalty is higher, the possibility of re-purchasing the product or service provided by the enterprise will also be higher in the future, so the profit of the e-retailer would also increase. Thus, this study believes that the consumers' loyalty intention shall include both the attitudinal and the behavioral levels.

\section{Advocacy intention}

Advocacy refers to the willingness of consumers to provide positive assessment of product or service provided by a supplier and strongly recommend it to other 
consumers [29]. This is commonly known as positive word of mouth marketing. When the consumers believe that there is a comfortable relationship established with the service supplier, then they advocate the service supplier [27] and recommend products or services to friends or acquaintances. Bendapudi and Berry [5] argued that advocacy includes propaganda and the positive words of mouth advocated for enterprises by customers who had good experiences during such consuming process. Thus, they provide a positive assessment, advocate, and provide free advertisement for the enterprise.

In summary, this study argues that advocacy intention is a representation of customers' loyalty. Business administrators can measure the willingness to provide positive recommendations by assessing customers [45].

\section{Willingness to pay more}

"Willingness to pay more" (WTPM) is considered as a customer's reaction, which is related to loyalty [35]. When customers have a particularly close relationship with one specific supplier, customers would have the willingness to pay higher prices where the supplier provides a valuable product [41]. Ligas and Chaudhuri [39] mentioned that WTPM is the customers' stated intent; this meaning that customers prefer certain supplier to other stores, they will be more willing to buy the product or service provided by such a supplier [39]. In addition, in terms of e-business, Kim et al. [36] claimed that WTPM refers to the willingness of customers to pay higher prices as to maintain the relationship with the e-retailer. In summary, this study trusts that WTPM is the preference of the customers for certain suppliers and the willingness of paying higher prices to purchase or use the product or service provided by such suppliers.

\section{Research methodology}

Based on the aforementioned literature review, this study first establishes the research structure and then infers the research hypothesis. Afterward, operational definitions are accordingly be provided for each of the variables and the measurement items are established. Lastly, the research design is systematically planned, including the study objects, questionnaire design, data analysis, and analytical methods.

\section{Research framework}

The purpose of this study is to analyze the impact to costumers' loyalty via the comparison of SERVQUAL, QES, and WPI in the e-commerce environment. This study further extends Allen and Meyer [1] research, which consist of the commitment formed by different motivations towards different types of organizations in the e-commerce environment; thus, affective, continuance, and normative commitment are discussed in terms of the impact to customers' loyalty. This study further explores the impact of different service quality dimensions towards the service quality to find the best service quality measurement model for e-commerce. Afterwards, the impact of the types of commitment towards costumers' loyalty behaviors is also identified. The research framework of this study is shown in Figs. 1 and 2. 


\section{Research hypotheses}

\section{Service quality}

As service quality is difficult to measure in an objective way, Parasuraman et al. [44] developed SERVQUAL to measure the service quality of the service industry in physical stores. SERVQUAL model is composed of reliability, responsiveness, assurance, empathy, and tangible. It is widely applied in different industries, such as banks, medical, and marketing industries [10, 15]. Moreover it has also been applied in e-commerce [32]. For this reason, this study also adopts these five dimensions to assess service quality of e-stores. (1) The higher the reliability that an e-store can provide to customers, the higher the degree of fulfillment of commitment to the e-store, causing the website commitment. Consumers to perceive that they have received better service quality. (2) Similarly, the higher the responsiveness of the e-store to consumers, the higher the timely

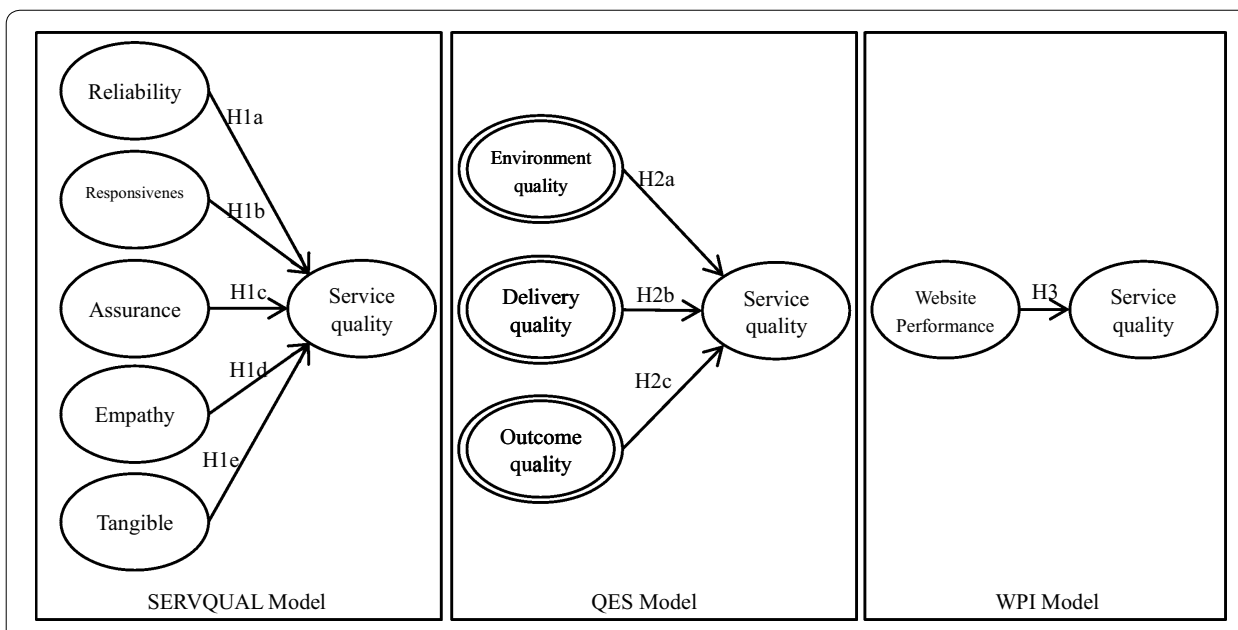

Fig. 1 Models comparison

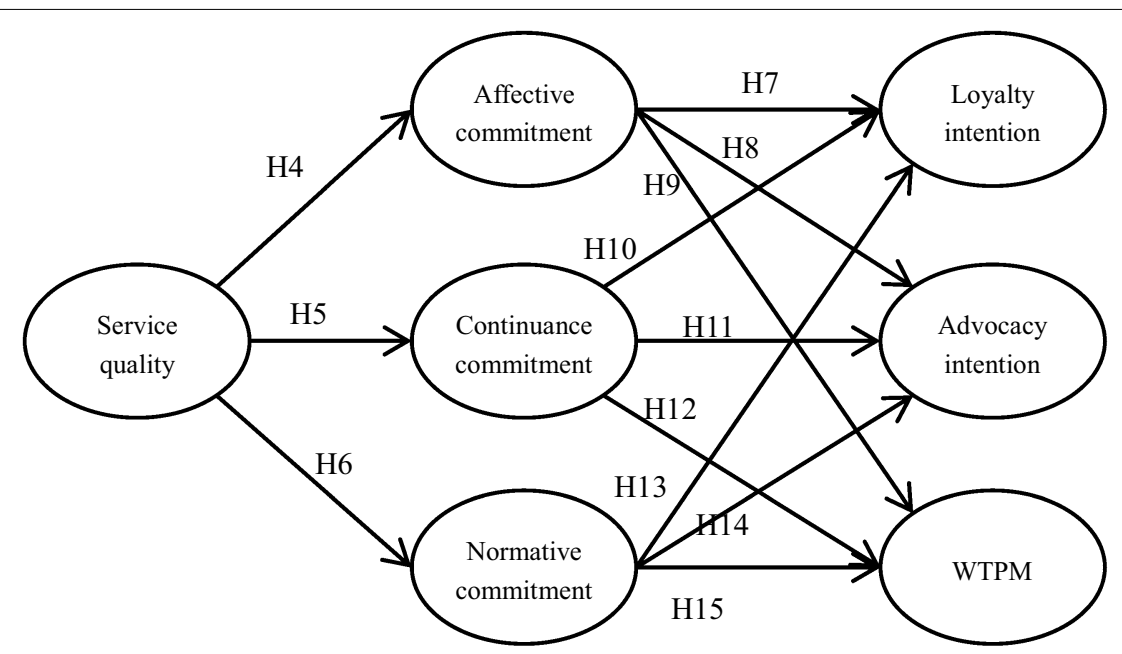

Fig. 2 Research framework of this study 
service that the e-store can provide to consumers; thus, the consumers feel that they have obtained better service quality [37]. (3) The higher the assurance that the e-store can provide to consumers, the better the privacy and safety of their transactions, which makes consumers think that they have better service guarantee, creating a higher confidence and trust towards the e-store; as such, customers perceive superior service quality as well. (4) The higher the empathy that an e-store can provide to consumers, the higher the degree of caring which is provided, in particular when it comes to individual needs; thus, the consumers experience better service quality. (5) The tangible that an e-store can bring to the consumers, which means a better visual appearance, navigation, search options, and layout, and the consumers obtain better service quality [32]. Based on the abovementioned statements, this study has the following research hypothesis:

H1a Reliability has a positive effect on service quality.

H1b Responsiveness has a positive effect on service quality.

H1c Assurance has a positive effect on service quality.

H1d Empathy has a positive effect on service quality.

H1e Tangible has a positive effect on service quality.

According to Fullerton [21], integrating service marketing and relationship marketing for the exploration of the impact of customer commitment towards customer loyalty, including environment quality, delivery quality, and outcome quality, can result in a significantly positive influence towards the overall service quality. Based on Yi and Gong [51]research, environment quality delivery quality, and outcome quality, have positive influences to service quality. (1) The higher the e-quality that an e-store can provide to consumers, the better the user interface that an e-store provides to consumers, thus, making consumers feel that they have received better service quality. (2) If an e-store can provide a higher delivery quality, it means that the consumers have a better interaction during the process of accepting the e-store's service; thus, consumers would believe that they have received better service quality. (3) Providing better outcome quality makes consumers believe that the e-store provides better service after actually receiving the service; that is to say, consumers obtains better service quality. Saba [47] indicated that system quality and information quality affected system use and user satisfaction. Summarily, this study has the following research hypothesis:

$\mathrm{H} 2 \mathrm{a} \quad$ Environment quality has a positive effect on service quality.

$\mathrm{H} 2 \mathrm{~b}$ Delivery quality has a positive effect on service quality.

H2c Outcome quality has a positive effect on service quality.

Last, based on Jeon [33] research of exploring the impact of the accommodation website's service quality towards customers' loyalty, it is discovered that the performance of the website has positive impact towards the perceived service quality. Bhattachary et al. [6] described that effective evaluation of system performance becomes critical and is served as an important instrument for quality monitoring and management. Based on this argument, this study considers that when the shopping website has better performances that the website can satisfy the demands and expectations of customers, 
customers obtain better service quality. Based on the above inferences, this study has the following research hypothesis:

H3 Website performance has a positive effect on service quality.

\section{Service quality and commitment}

Chuang and Chen [11] recognized the importance of social influences toward personal commitment and engagement of bicycling activities and the related virtual customer environments (VCEs). In Venetis and Ghauri [50] research related to the exploration of service quality and customer retention rate, it is discovered that service quality has a significantly positive impact on affective and continuance commitment. According to Fullerton [21] research, service quality has positive relationship with affective and continuance commitment. Based on the aforementioned perspectives, this study believes when an e-store provide better service quality to consumers, the affection of consumers towards the e-retailers would be stronger, and so do their preferences, which would eventually increase the emotional attachment of the individual towards an e-store. Thus, consumers would give more affective commitment for the e-retailers. On the other hand, if an e-store provide better service quality to consumers, consumers would be more dependent over the service provided by an e-store. The higher the dependence, the higher the conversion cost. Thus, the consumers would not abandon the website easily. The consumers would give more and more continuance commitment towards the e-retailer. Normative commitment comes from the obligation level that the consumers feel towards an e-store. When an e-store provides better and better services, consumers would feel a sense of obligation to maintain the relationship with the e-retailers; therefore, they would give more and more normative commitment. Similarly, this study has the following research hypothesis:

H4 Service quality has a positive effect on affective commitment.

H5 Service quality has a positive effect on continuance commitment.

H6 Service quality has a positive effect on normative commitment.

\section{Affective commitment and behavioral intention}

In terms of the exploring antecedents and consequences of commitment in marketing survey, Cater and Zabkar [9] mentioned that affective commitment has a positive influence on customer loyalty. As for affective commitment and loyalty behavior with retailers in e-commerce environment, Davis-Sramek et al. [14] suggested that there is a positive causal relationship between affective commitment and loyalty behavior. Fullerton [23] study of the impact of customers' commitment towards relationship marketing discovered that, affective commitment has a positive effect on advocacy intention. Lee et al. [38] indicated that a positive influential relationship is established between affective commitment and advocacy intention. In terms of the degree satisfaction, trust, and commitment towards advocacy intention, Fullerton [24] confirmed that affective commitment is a key element customers' advocacy. Fullerton [21] indicated that affective commitment positively affects the acceptance of the intention of increase in price. Ho and Wang [30] showed that customer-community relationships can enhance post-purchase behaviors by improving individual community 
participation or identification. When consumers prefer certain supplier to other stores, they will be more willing to buy the product or service provided by such supplier [39]. Therefore, based on the above points of view, this study has the following research hypothesis:

H7 Affective commitment has a positive effect on loyalty intention.

H8 Affective commitment has a positive effect on advocacy intention.

H9 Affective commitment has a positive effect on WTPM.

\section{Continuance commitment and behavioral intention}

Regarding the study of customer relationship in the banking industry, Bloemer and Odekerken-Schröder [7] had an in-depth study between customers' commitment and customer loyalty. The analytical result showed that continuance commitment has a negative impact on the customer loyalty, and whenever the benefit provided by the bank is higher than the conversion cost, the continuance commitment will become the obstacle of leaving this entity. Gounaris [26] also confirmed that in business-tobusiness relationship, continuance relationship has negative impact over the maintenance of relationship and investment. In Fullerton [22] study, concerning the verification of the impact of loyalty via the integration of relationship marketing and brand loyalty, continuance commitment has negative relationship with the advocacy intention of consumers towards the brand. Later, regarding the impact of customer commitment towards relationship marketing, Fullerton [23] discovered the negative impact of continuance commitment to advocacy intention. In the banking industry, Bloemer and Odekerken-Schröder [7] pointed out that continuance commitment has negative relationship with words of mouth marketing. According to Fullerton [21] research, the analytical result indicated that there is negative relationship between continuance commitment and WTPM. Moreover, Bloemer and Odekerken-Schröder [7] described that continuance commitment has a negative causal relationship with price insensitivity: The higher the continuance commitment, the higher the sensitivity towards the price. Based on the above perspectives, this study has the following research hypothesis:

H10 Continuance commitment has a negative effect on loyalty intention.

H11 Continuance commitment has a negative effect on advocacy intention.

H12 Continuance commitment has a negative effect on WTPM.

\section{Normative commitment and behavioral intention}

In Hur et al. [31] research with regard to the customer commitment and loyalty behavior in the telecommunication service industry, the empirical results showed that normative commitment affects positively the customer retention. According to Bloemer and Odekerken-Schröder [7], the analytical result showed that normative commitment has a close relationship with customer loyalty, and normative commitment has positive impact over advocacy intention and WTPM. Summarily, this study has the following research hypothesis: 
H13 Normative commitment has a positive effect on loyalty intention.

H14 Normative commitment has a positive effect on advocacy intention.

H15 Normative commitment has a positive effect on WTPM.

\section{Research design \\ Sampling design}

The central issue of this study is the elements of service quality that influences consumers' loyalty behaviors during the online shopping process. Thus, the objects of this study are Internet users who actually trade on shopping websites in Taiwan. Through surveys, this study target consumers who have online shopping experiences, and a certain quantity of samples is needed to reach the study requirement. This study collects a wide range of information, so gender, age, and educational background are not restricted in this study.

Two questionnaires were identified. (1) Convenience sampling was executed for the pilot study. Based on the results, the items were adjusted minimally and a formal questionnaire was developed. An online questionnaire was distributed for convenience sampling so as to collect the necessary amount of samples. The formal questionnaire was designed with Google forms. The link of the questionnaire was posted in BBS and social networks so that it could be completed voluntarily. (2) Invalid questionnaires were deleted when refining the samples so as to increase the reliability and validity of the information.

\section{Questionnaire design}

A close-ended two-phase questionnaire was given and was divided into four major parts in the following five directions. (1) The first part was an inquiry of the subjects' basic background for matrix background analysis. (2) The second to the fourth parts were the main measurement dimensions, including service quality, commitment, and customer loyalty. (3) A Likert seven point scales (strongly disagree, disagree, somewhat disagree, average, somewhat agree, agree, and strongly agree) was used as the measurement method. For "strongly disagree" a point was given, points were added in the aforementioned order, with 7 points for "strongly agree". Furthermore, the research variables are based on the theoretical basis provided by experts and scholars as well as the literature review. The definitions of the variable for measurement were clearly described together with their sources in the literature review section. These shall be considered as their face validity. (4) A pretest of the first stage was delivered to experts and scholars of related disciplines to modify the questionnaire for avoiding any error generated by the misunderstanding or incomprehension of the questions. (5) A pilot study of the second stage was delivered to 10-20 persons to complete the questionnaire. They were asked to further modify inappropriate wordings or ambiguous questions to reduce the possibility of ambiguous or incomprehensible phrases. Similarly, the analytical result of the questionnaire should be validated by content validity.

\section{Analysis method}

After recycling the questionnaires, the data was analyzed through SPSS 20.0, PLS 2.0, and LISREL 8.70 . The analysis process includes the descriptive analysis of the sample 
characteristics, reliability and validity analysis, and the structural equation modeling (SEM) analysis for the verification of the causal relationship of the research hypotheses. (1) Descriptive analysis: After recycling the collected samples, descriptive statistical analysis by SPSS 20.0, including the mean, standard deviation, frequency distribution, and others, is used to analyze the statistic nature of the given data, such as gender, purchase experience, and average time of online shopping, to understand the characteristics of the samples. (2) SEM analysis: The convergent validity of the items and the dimensions and the discriminant validity of the indicators for the goodness of fit among the dimensions were measured through PLS 2.0. The measurement model was verified through LISREL 8.70. (3) Path analysis: The structural model is done to verify the causal relationship of each path, to understand the goodness of fit of the structural model, and to verify the research hypotheses.

\section{Data analysis}

This section is divided into five subsections, which are descriptive statistical analysis, measurement model analysis, structural model analysis, hypotheses analysis, and model comparison. SPSS 20.0, PLS 2.0, and LISREL 8.70 are used to compile and analyze the questionnaire data and to verify the hypotheses of this research.

\section{Descriptive statistical analysis}

Through Facebook and the PTT Bulletin Board System, 466 online questionnaires were returned, 11 of which were deemed to be invalid samples. As a result, there were 455 valid samples, accounting for $97.7 \%$ of the total questionnaires. The 455 samples are done by a descriptive statistical analysis to understand all the pictures of samples. Items of analysis include gender, age, educational level, profession, average month income, online shopping experience, average shopping frequency, daily average time using shopping website, and the most visited shopping website. Table 2 summarizes the characteristics of the respondents.

\section{Measurement model analysis}

Based on the study of Anderson and Gerbing [2], this measurement model analysis is proceeded in the reliability, validity (i.e., convergent validity and discriminant validity), and the goodness of fit of the model, which are measured and verified by Cronbach's $\alpha$ coefficient and confirmatory factor.

\section{Reliability analysis}

The consistency and the stability of the questionnaire items were measured through Cronbach's $\alpha$ coefficient. Based on Nunnally [42] study, if Cronbach's $\alpha$ coefficient is bigger or equal to 0.7 , it can be considered as highly reliable. The results of the reliability analysis are shown in Table 3. From the table, it is shown that the Cronbach's $\alpha$ coefficients of the variables are between 0.706 and 0.928 , all bigger than 0.7. Thus, all the questionnaire items are considered as high reliability, and can also be considered high to show a degree of credibility. 
Table 2 Demographics information of respondents $(n=455)$

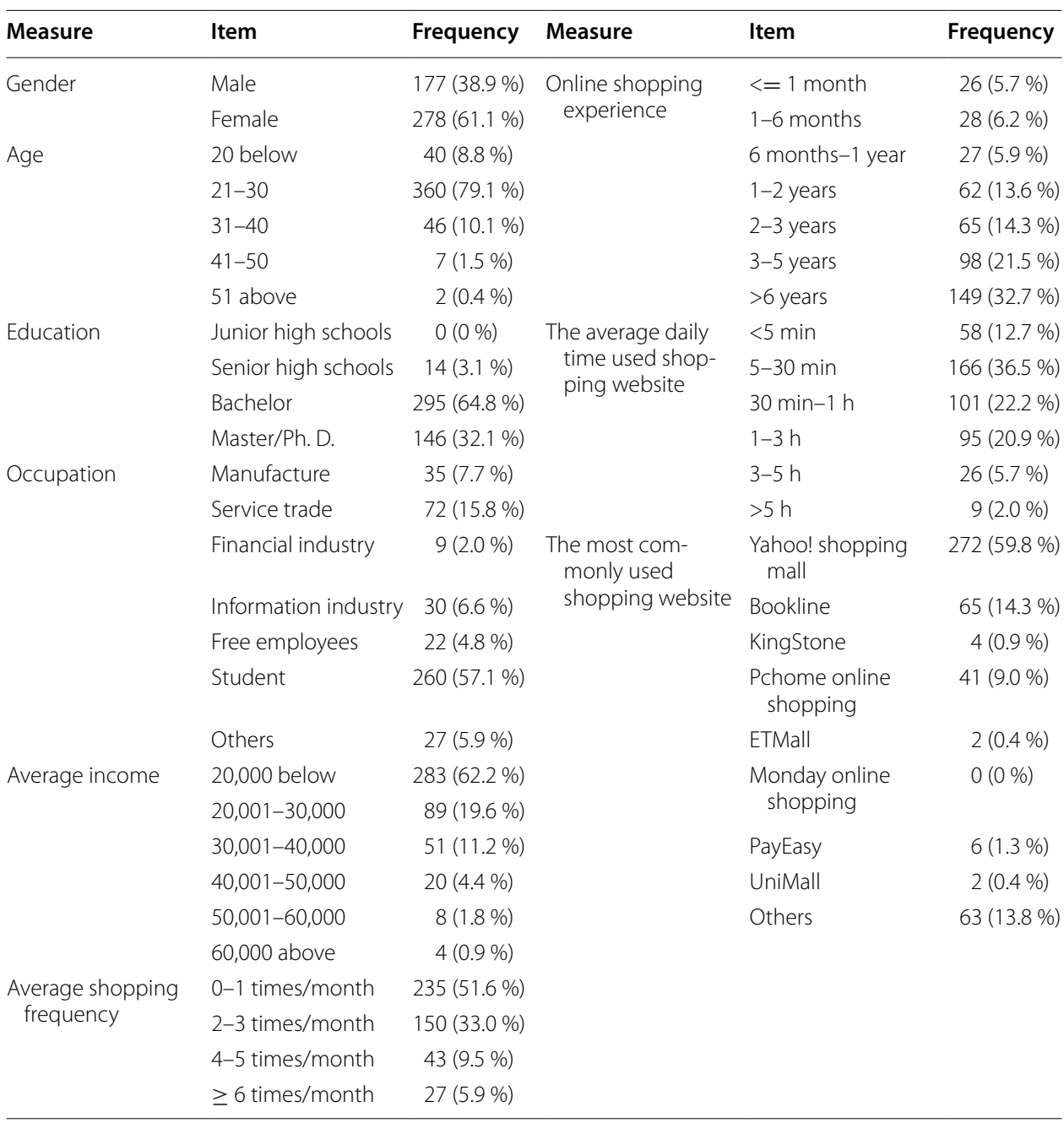

Validity analysis

Validity refers to quality and accuracy of the measurements of an instrument, and it is divided into construct validity, criterion validity, and content validity. Construct validity is composed of convergent validity and discriminant validity, which are used to measure the potential dimensions in this study. Within the potential facet, each of the measurement variables highly correlated, meaning that the measurement variable converges into a facet that has convergent validity. If the measurement variables are not within the same potential facet, the correlation low, meaning that it has discriminant validity.

Convergent validity In terms of convergent validity analysis, the following measurement standard is used to measure convergent validity [3]. (1) The standardized factor loadings of the observed variables shall be bigger than 0.7 [28]. (2) Squared multiple correlations $(\mathrm{SMC})$ are used to measure the intensity of the individual variable over the potential dimension. The SMC value shall be bigger than 0.5 , meaning that the measurement variable has high credibility. (3) Composite reliability (CR) refers to the consistency of the 
Table 3 Reliability statistics information

\begin{tabular}{|c|c|c|c|c|c|}
\hline Model & Construct & Cronbach's a & Model & Construct & Cronbach's a \\
\hline \multirow[t]{5}{*}{ SERVQUAL } & Reliability & 0.913 & \multirow[t]{3}{*}{ QES } & $\begin{array}{l}\text { Outcome quality } \\
\text { Reliability }\end{array}$ & 0.913 \\
\hline & Responsiveness & 0.868 & & Function benefit & 0.853 \\
\hline & Assurance & 0.910 & & Emotional benefit & 0.834 \\
\hline & Empathy & 0.874 & WPI & $\begin{array}{l}\text { Website perfor- } \\
\text { mance }\end{array}$ & 0.887 \\
\hline & Tangible & 0.782 & \multirow{7}{*}{$\begin{array}{l}\text { The framework } \\
\text { of this study }\end{array}$} & Service quality & 0.928 \\
\hline \multirow[t]{6}{*}{ QES } & $\begin{array}{l}\text { Environment quality } \\
\text { Graphic quality }\end{array}$ & 0.871 & & $\begin{array}{l}\text { Affective commit- } \\
\text { ment }\end{array}$ & 0.842 \\
\hline & Clarity of layout & 0.911 & & $\begin{array}{l}\text { Continuance com- } \\
\text { mitment }\end{array}$ & 0.867 \\
\hline & $\begin{array}{l}\text { Delivery quality } \\
\text { Attractiveness of selection }\end{array}$ & 0.863 & & $\begin{array}{l}\text { Normative commit- } \\
\text { ment }\end{array}$ & 0.706 \\
\hline & Information quality & 0.852 & & Loyalty intention & 0.880 \\
\hline & Ease of use & 0.894 & & Advocacy intention & 0.891 \\
\hline & Technical quality & 0.901 & & WTPM & 0.905 \\
\hline
\end{tabular}

variables within the potential dimensions. The standard value shall be bigger than 0.6. The higher the CR value, the higher the consistency of the variables, meaning the better predictability. (4) Average variance extracted (AVE) refers to the average explanatory ability of the measurement variables within the potential dimensions. The standard value shall be bigger than 0.5 .

From the collected questionnaires, the three models in the research framework of Fig. 1 with various constructs and items are compiled and analyzed, and their abbreviations are formatted. For example, there are four items in the reliability (abbreviated as REL) of construct of SERVQUAL, which are abbreviated as REL1-REL4. The analytical results of the three models are shown in Table 4. Based on the above evaluation criteria, all the standardized factor loadings of the variables (items) in the three models are bigger than the standardized value 0.7 except for WP3 and WP7 that are close and round to 0.7. As for the SMC value, all the variables have bigger than 0.5 except for WP3, WP7, and $\mathrm{NC1}$, which are all rounded to 0.5 ; therefore, they are not deleted. All the AVE values of the three models are between 0.560 and 0.879 , all having bigger than 0.5. Thus, this information shows that there are good internal qualities in the three models. Furthermore, all the CR values are between 0.830 and 0.954 , which are bigger than 0.6. The above information implies that the three models have good internal consistency.

Discriminant validity Discriminant validity aims to measure all the potential dimensions. If the correlation degree of two dimensions is very low, it means that having discriminant validity exists. Based on the study of Fornell and Larcke [19], if the square root of the AVE value at a potential dimension is bigger than the correlation coefficient with other potential dimensions, and then the existence of the discriminant validity is proven. Tables 5, 6, 7 and 8 show the discriminant validity results of the three models, respectively. As the empirical results are shown in Tables 5, 6, 7 and 8, it is clearly that the square roots of the AVE values at all potential dimensions are bigger than the related correlation coefficient when compared to other dimensions. Therefore, good discriminant validity exists in all the potential dimensions of the three models in this study. 
Table 4 Model convergent validity information

\begin{tabular}{|c|c|c|c|c|c|c|}
\hline Model & Construct & Item & $\begin{array}{l}\text { Factor } \\
\text { loading }\end{array}$ & SMC & AVE & CR \\
\hline \multirow[t]{18}{*}{ SERVQUAL } & Reliability (REL) & REL1 & 0.877 & 0.770 & 0.793 & 0.939 \\
\hline & & REL2 & 0.903 & 0.816 & & \\
\hline & & REL3 & 0.860 & 0.740 & & \\
\hline & & REL4 & 0.919 & 0.845 & & \\
\hline & Responsiveness (RES) & RES1 & 0.815 & 0.665 & 0.716 & 0.910 \\
\hline & & RES2 & 0.878 & 0.770 & & \\
\hline & & RES3 & 0.844 & 0.713 & & \\
\hline & & RES4 & 0.848 & 0.718 & & \\
\hline & Assurance (ASS) & ASS1 & 0.920 & 0.847 & 0.787 & 0.936 \\
\hline & & ASS2 & 0.859 & 0.738 & & \\
\hline & & ASS3 & 0.886 & 0.786 & & \\
\hline & & ASS4 & 0.881 & 0.775 & & \\
\hline & Empathy (EMP) & EMP1 & 0.854 & 0.729 & 0.725 & 0.913 \\
\hline & & EMP2 & 0.861 & 0.741 & & \\
\hline & & EMP3 & 0.865 & 0.748 & & \\
\hline & & EMP4 & 0.827 & 0.683 & & \\
\hline & Tangibles (ERQ) & ERQ1 & 0.897 & 0.804 & 0.821 & 0.902 \\
\hline & & ERQ2 & 0.915 & 0.837 & & \\
\hline \multirow[t]{26}{*}{ QES } & Graphic quality (GQ) & GQ1 & 0.876 & 0.767 & 0.794 & 0.920 \\
\hline & & GQ2 & 0.901 & 0.812 & & \\
\hline & & GQ3 & 0.888 & 0.789 & & \\
\hline & Clarity of layout (COL) & COL1 & 0.908 & 0.824 & 0.849 & 0.944 \\
\hline & & $\operatorname{COL} 2$ & 0.929 & 0.863 & & \\
\hline & & COL3 & 0.928 & 0.861 & & \\
\hline & Attractiveness of selection (AOS) & AOS1 & 0.942 & 0.887 & 0.879 & 0.936 \\
\hline & & AOS2 & 0.934 & 0.872 & & \\
\hline & Information quality (IFQ) & IFQ1 & 0.869 & 0.755 & 0.771 & 0.910 \\
\hline & & IFQ2 & 0.897 & 0.805 & & \\
\hline & & IFQ3 & 0.869 & 0.755 & & \\
\hline & Ease of use (EOU) & EOU1 & 0.870 & 0.757 & 0.758 & 0.926 \\
\hline & & EOU2 & 0.848 & 0.719 & & \\
\hline & & EOU3 & 0.901 & 0.812 & & \\
\hline & & EOU4 & 0.864 & 0.746 & & \\
\hline & Technical quality (TQ) & TQ1 & 0.903 & 0.815 & 0.836 & 0.938 \\
\hline & & TQ2 & 0.941 & 0.885 & & \\
\hline & & TQ3 & 0.899 & 0.808 & & \\
\hline & Reliability (REL) & REL1 & 0.874 & 0.764 & 0.793 & 0.939 \\
\hline & & REL2 & 0.900 & 0.810 & & \\
\hline & & REL3 & 0.865 & 0.748 & & \\
\hline & & REL4 & 0.922 & 0.850 & & \\
\hline & Function benefit (FB) & FB1 & 0.926 & 0.857 & 0.872 & 0.932 \\
\hline & & FB2 & 0.941 & 0.885 & & \\
\hline & Emotional benefit (EB) & EB1 & 0.941 & 0.885 & 0.857 & 0.923 \\
\hline & & EB2 & 0.909 & 0.826 & & \\
\hline
\end{tabular}


Table 4 continued

\begin{tabular}{|c|c|c|c|c|c|c|}
\hline Model & Construct & Item & $\begin{array}{l}\text { Factor } \\
\text { loading }\end{array}$ & SMC & AVE & CR \\
\hline \multirow[t]{8}{*}{$\overline{\text { WPI }}$} & \multirow[t]{8}{*}{ Website performance (WP) } & WP1 & 0.800 & 0.640 & \multirow[t]{8}{*}{0.560} & \multirow[t]{8}{*}{0.910} \\
\hline & & WP2 & 0.838 & 0.702 & & \\
\hline & & WP3 & 0.682 & 0.465 & & \\
\hline & & WP4 & 0.730 & 0.533 & & \\
\hline & & WP5 & 0.734 & 0.539 & & \\
\hline & & WP6 & 0.719 & 0.517 & & \\
\hline & & WP7 & 0.698 & 0.487 & & \\
\hline & & WP8 & 0.761 & 0.579 & & \\
\hline \multirow{23}{*}{$\begin{array}{l}\text { The framework } \\
\text { of this study }\end{array}$} & \multirow[t]{3}{*}{ Service quality (SQ) } & SQ1 & 0.936 & 0.876 & \multirow[t]{3}{*}{0.874} & \multirow[t]{3}{*}{0.954} \\
\hline & & SQ2 & 0.944 & 0.891 & & \\
\hline & & SQ3 & 0.924 & 0.854 & & \\
\hline & \multirow[t]{3}{*}{ Affective commitment (AC) } & $\mathrm{AC} 1$ & 0.838 & 0.702 & \multirow[t]{3}{*}{0.758} & \multirow[t]{3}{*}{0.904} \\
\hline & & AC2 & 0.863 & 0.745 & & \\
\hline & & AC3 & 0.910 & 0.828 & & \\
\hline & \multirow[t]{3}{*}{ Continuance commitment (CC) } & $\mathrm{CC} 1$ & 0.878 & 0.771 & \multirow[t]{3}{*}{0.789} & \multirow[t]{3}{*}{0.918} \\
\hline & & $\mathrm{CC} 2$ & 0.907 & 0.823 & & \\
\hline & & $\mathrm{CC} 3$ & 0.879 & 0.773 & & \\
\hline & \multirow[t]{3}{*}{ Normative commitment (NC) } & NC1 & 0.703 & 0.494 & \multirow[t]{3}{*}{0.620} & \multirow[t]{3}{*}{0.830} \\
\hline & & NC2 & 0.801 & 0.642 & & \\
\hline & & NC3 & 0.852 & 0.726 & & \\
\hline & \multirow[t]{4}{*}{ Loyalty intention (LI) } & LI1 & 0.887 & 0.787 & \multirow[t]{4}{*}{0.740} & \multirow[t]{4}{*}{0.919} \\
\hline & & LI2 & 0.902 & 0.814 & & \\
\hline & & LI3 & 0.905 & 0.819 & & \\
\hline & & LI4 & 0.733 & 0.537 & & \\
\hline & \multirow[t]{4}{*}{ Advocacy intention (Al) } & Al1 & 0.879 & 0.773 & \multirow[t]{4}{*}{0.753} & \multirow[t]{4}{*}{0.924} \\
\hline & & $\mathrm{Al} 2$ & 0.850 & 0.723 & & \\
\hline & & $\mathrm{Al} 3$ & 0.861 & 0.741 & & \\
\hline & & Al4 & 0.881 & 0.776 & & \\
\hline & \multirow[t]{3}{*}{ Willingness to pay more (WTPM) } & WTPM1 & 0.917 & 0.841 & \multirow[t]{3}{*}{0.840} & \multirow[t]{3}{*}{0.940} \\
\hline & & WTPM2 & 0.919 & 0.845 & & \\
\hline & & WTPM3 & 0.914 & 0.835 & & \\
\hline
\end{tabular}

\section{Measurement model fit statistics}

The overall model fit, proposed by Bagozzi and Yi [3], is used to measure the goodnessof-fit information of the three models in this study between the hypothetical model and the actual model. The evaluation indicators for the goodness-of-fit are divided into three categories: absolute fit measures, incremental fit measures, and parsimonious fit measures. Table 9 lists the model fit indices in the three models. From Table 9, the analytical results in the three models are compiled and analyzed as follows, respectively.

1. SERVQUAL The absolute GFI is: $\chi^{2}=2004.84, x^{2} / \mathrm{df}=2.81$, GFI $=0.81$, AGFI $=0.77$, RMR $=0.12$, and RMSEA $=0.07$. The incremental fix index is: $\mathrm{NFI}=0.97$, NNFI $=0.98, \mathrm{CFI}=0.98$, IFI $=0.98$, and RFI $=0.97$. The parsimonious goodness-of-fit index is: PGFI $=0.67, \mathrm{PNFI}=0.84$, and $\mathrm{CN}=183.02$. From the above indicators, $\chi^{2}$, GFI, AGFI, RMR, and $\mathrm{CN}$ have not met the standard values, and the rests are acceptable. 
Table 5 Discriminant validity of SERVQUAL

\begin{tabular}{lllllll}
\hline & REL & RES & ASS & EMP & ERQ & SQ \\
\hline REL & 0.890 & & & & & \\
RES & 0.834 & 0.846 & & & \\
ASS & 0.833 & 0.816 & 0.887 & & & \\
EMP & 0.594 & 0.633 & 0.638 & 0.852 & & \\
ERQ & 0.561 & 0.579 & 0.614 & 0.672 & 0.906 & \\
SQ & 0.758 & 0.731 & 0.744 & 0.625 & 0.534 & 0.935 \\
\hline
\end{tabular}

Table 6 Discriminant validity of QES

\begin{tabular}{|c|c|c|c|c|c|c|c|c|c|c|}
\hline & GQ & $\mathrm{COL}$ & AOS & IFQ & EOU & TQ & REL & FB & EB & SQ \\
\hline GQ & 0.891 & & & & & & & & & \\
\hline $\mathrm{COL}$ & 0.703 & 0.921 & & & & & & & & \\
\hline AOS & 0.460 & 0.460 & 0.938 & & & & & & & \\
\hline IFQ & 0.665 & 0.655 & 0.623 & 0.878 & & & & & & \\
\hline EOU & 0.595 & 0.629 & 0.551 & 0.663 & 0.871 & & & & & \\
\hline TQ & 0.555 & 0.578 & 0.546 & 0.614 & 0.751 & 0.914 & & & & \\
\hline REL & 0.506 & 0.564 & 0.358 & 0.565 & 0.632 & 0.623 & 0.890 & & & \\
\hline $\mathrm{FB}$ & 0.539 & 0.619 & 0.535 & 0.628 & 0.740 & 0.722 & 0.635 & 0.934 & & \\
\hline EB & 0.515 & 0.578 & 0.468 & 0.620 & 0.669 & 0.594 & 0.541 & 0.677 & 0.925 & \\
\hline SQ & 0.499 & 0.525 & 0.336 & 0.506 & 0.598 & 0.583 & 0.756 & 0.620 & 0.532 & 0.935 \\
\hline
\end{tabular}

Table 7 Discriminant validity of WPI

\begin{tabular}{lll}
\hline & WP & SQ \\
\hline WP & 0.748 & \\
SQ & 0.712 & 0.935 \\
\hline
\end{tabular}

Table 8 Discriminant validity of this study

\begin{tabular}{llllllll}
\hline & SQ & AC & CC & NC & LI & Al & WTPM \\
\hline SQ & 0.935 & & & & & & \\
AC & 0.320 & 0.871 & & & & & \\
CC & 0.145 & 0.521 & 0.888 & & & \\
NC & 0.411 & 0.632 & 0.626 & 0.788 & & \\
LI & 0.436 & 0.585 & 0.429 & 0.561 & 0.860 & & \\
Al & 0.547 & 0.629 & 0.417 & 0.626 & 0.679 & 0.868 & \\
WTPM & 0.321 & 0.387 & 0.423 & 0.524 & 0.436 & 0.553 & 0.916 \\
\hline
\end{tabular}

2. QES The absolute GFI is: $\chi^{2}=3764.31, \chi^{2} / \mathrm{df}=3.74$, GFI $=0.75$, AGFI $=0.69$, $\mathrm{RMR}=0.37$, and RMSEA $=0.08$. The incremental fix index is: NFI $=0.97$, NNFI $=0.97$, CFI $=0.98$, IFI $=0.98$, and RFI $=0.96$. The parsimonious goodnessof-fit index is: PGFI $=0.62$, PNFI $=0.83$, and $\mathrm{CN}=135.40$. Regarding the above 
Table 9 Model fit indices information

\begin{tabular}{|c|c|c|c|c|}
\hline Model & Fit index & Conceptual model & Recommended criterion & Judgment \\
\hline \multirow[t]{14}{*}{ SERVQUAL } & $x^{2}$ & $2004.84(p=0.000)$ & - & - \\
\hline & $x^{2} /$ d.f. & 2.812 & $<3$ & Yes \\
\hline & GFI & 0.81 & $>0.9$ & No \\
\hline & AGFI & 0.77 & $>0.9$ & No \\
\hline & RMR & 0.12 & $<0.08$ & No \\
\hline & RMSEA & 0.07 & $<0.08$ & Yes \\
\hline & $\mathrm{NFI}$ & 0.97 & $>0.9$ & Yes \\
\hline & NNFI & 0.98 & $>0.9$ & Yes \\
\hline & $\mathrm{CFI}$ & 0.98 & $>0.9$ & Yes \\
\hline & $|F|$ & 0.98 & $>0.9$ & Yes \\
\hline & RFI & 0.97 & $>0.9$ & Yes \\
\hline & PGFI & 0.67 & $>0.5$ & Yes \\
\hline & PNFI & 0.84 & $>0.5$ & Yes \\
\hline & $C N$ & 183.02 & $>200$ & No \\
\hline \multirow[t]{14}{*}{ QES } & $x^{2}$ & $3764.31(p=0.000)$ & - & - \\
\hline & $x^{2} / d f$ & 3.74 & $<3$ & No \\
\hline & GFI & 0.75 & $>0.9$ & No \\
\hline & AGFI & 0.69 & $>0.9$ & No \\
\hline & RMR & 0.37 & $<0.08$ & No \\
\hline & RMSEA & 0.08 & $<0.08$ & Yes \\
\hline & $\mathrm{NFI}$ & 0.97 & $>0.9$ & Yes \\
\hline & NNFI & 0.97 & $>0.9$ & Yes \\
\hline & $\mathrm{CFI}$ & 0.98 & $>0.9$ & Yes \\
\hline & $|F|$ & 0.98 & $>0.9$ & Yes \\
\hline & RFI & 0.96 & $>0.9$ & Yes \\
\hline & PGFI & 0.62 & $>0.5$ & Yes \\
\hline & PNFI & 0.83 & $>0.5$ & Yes \\
\hline & $\mathrm{CN}$ & 135.40 & $>200$ & No \\
\hline \multirow[t]{14}{*}{ WPI } & $x^{2}$ & $1390.18(p=0.000)$ & - & - \\
\hline & $x^{2} / d f$ & 3.42 & $<3$ & Yes \\
\hline & GFI & 0.82 & $>0.9$ & No \\
\hline & AGFI & 0.78 & $>0.9$ & No \\
\hline & RMR & 0.11 & $<0.08$ & No \\
\hline & RMSEA & 0.13 & $<0.08$ & No \\
\hline & $\mathrm{NFI}$ & 0.96 & $>0.9$ & Yes \\
\hline & NNFI & 0.97 & $>0.9$ & Yes \\
\hline & $\mathrm{CFI}$ & 0.97 & $>0.9$ & Yes \\
\hline & $|F|$ & 0.97 & $>0.9$ & Yes \\
\hline & RFI & 0.96 & $>0.9$ & Yes \\
\hline & PGFI & 0.67 & $>0.5$ & Yes \\
\hline & PNFI & 0.84 & $>0.5$ & Yes \\
\hline & $\mathrm{CN}$ & 156.19 & $>200$ & No \\
\hline
\end{tabular}

indicators, $\chi^{2}, \chi^{2} / \mathrm{df}$, GFI, AGFI, RMR, and $\mathrm{CN}$ have not met the standard values, but the rests are acceptable.

3. WPI The absolute GFI is: $\chi^{2}=1390.18, \chi^{2} / \mathrm{df}=3.42$, GFI $=0.82$, AGFI $=0.78$, $\mathrm{RMR}=0.11$, and RMSEA $=0.13$. The incremental fix index is: NFI $=0.96$, 
$\mathrm{NNFI}=0.97, \mathrm{CFI}=0.97, \mathrm{IFI}=0.97$, and $\mathrm{RFI}=0.96$. The parsimonious goodnessof-fit index is: PGFI $=0.67$, PNFI $=0.84$, and $\mathrm{CN}=156.19$. From the above indicators, $\chi^{2}$, GFI, AGFI, RMR, RMSEA, and CN have not met the standard values, while the rests are acceptable.

Overall, although not all goodness-of-fits of the three models meet the standard values, they still can be acceptable. In further comparison, five indicators, six indicators, and six indicators of goodness-of-fits in SERVQUAL model, QES model, and WPI model have not met the standard values, respectively. Therefore, it is clear that the goodnessof-fit of the SERVQUAL model has a better result than that of the other models.

\section{Structural model evaluation}

This study uses LISREL 8.70 to test the causal relationship between the potential dimensions for the constructed structural model evaluation and to measure the significant degree of the paths between the dimensions. The testing results are shown in Table 10. Moreover, the explanatory ability $\left(R^{2}\right)$ of the potential dependent variables (or called dimensions) within the constructed structural model is also verified. Figures 3 and 4 depict the verification results. The further analytical results will be described in the next subsection.

\section{Research hypothesis analysis}

The testing results of the research hypotheses in this study are described as follows:

\section{Hypothesis verification of the three models to service quality}

1. SERVQUAL Fig. 3 and Table 10, shows that H1a, H1c, and H1d are empirically proven, but H1b and H1e are not supported. (a) H1a: The testing result matches with the Lee and Lin's point of view [37]. The higher the reliability provided by the shopping website, the greater the impact on consumers' feelings towards the service quality of the shopping website, since consumers believe that they have obtained better service quality. (b) H1b: When consumers believe that the degree of responsiveness is higher, the service quality does not significantly increase. The reason may be that with the booming of the Internet, consumers can quickly obtain information and service through it; thus, timely service is considered as a required service for every shopping website. (c) H1c: The testing result has evidence to the research hypothesis. That is, the higher the assurance provided by the shopping website, the greater the impact consumers feelings towards the service quality of the shopping website, since the consumers believe that they have obtained better service quality. (d) H1d: The testing result also obtains evidence with the research hypothesis: The higher the empathy provided by the shopping website, the greater the impact on customers' feelings towards service quality of shopping website, since consumers believe that they have obtained better service quality. (e) H1e: A reasonable explanation is that the presentation form of the website may interface design negatively, and the consumers put more emphasis on the consumption process than other factors when compared to the other dimensions. The tangible has not significant impact on service quality among the real substantiation services provided. 
Table 10 Results of hypotheses testing

\begin{tabular}{|c|c|c|c|c|c|}
\hline Model & Hypothesis & Related & Coefficient & t-value & Support \\
\hline \multirow[t]{5}{*}{ SERVQUAL } & H1a: reliability $\rightarrow$ service quality & + & 0.41 & $2.64^{* *}$ & Yes \\
\hline & $\mathrm{H} 1 \mathrm{~b}$ : responsiveness $\rightarrow$ service quality & + & 0.01 & 0.04 & No \\
\hline & H1c: assurance $\rightarrow$ service quality & + & 0.28 & $2.39^{*}$ & Yes \\
\hline & H1d: empathy $\rightarrow$ service quality & + & 0.26 & $3.98^{* * *}$ & Yes \\
\hline & H1e: tangible $\rightarrow$ service quality & + & -0.01 & -0.13 & No \\
\hline \multirow[t]{3}{*}{ QES } & $\begin{array}{l}\text { H2a: environment quality } \rightarrow \text { service } \\
\text { quality }\end{array}$ & + & 0.12 & $3.02^{* *}$ & Yes \\
\hline & H2b: delivery quality $\rightarrow$ service quality & + & 0.44 & $4.78^{* * *}$ & Yes \\
\hline & H2c: outcome quality $\rightarrow$ service quality & + & 0.36 & $4.26^{* * *}$ & Yes \\
\hline WPI & $\begin{array}{l}\text { H3: website performance } \rightarrow \text { service } \\
\text { quality }\end{array}$ & + & 0.80 & $17.26^{* * *}$ & Yes \\
\hline \multirow[t]{12}{*}{$\begin{array}{l}\text { The framework } \\
\text { of this study }\end{array}$} & $\begin{array}{l}\text { H4: service quality } \rightarrow \text { affective commit- } \\
\text { ment }\end{array}$ & + & 0.32 & $6.19^{* * *}$ & Yes \\
\hline & $\begin{array}{l}\text { H5: service quality } \rightarrow \text { continuance com- } \\
\text { mitment }\end{array}$ & + & 0.21 & $4.06^{* * *}$ & Yes \\
\hline & $\begin{array}{l}\text { H6: service quality } \rightarrow \text { normative com- } \\
\text { mitment }\end{array}$ & + & 0.71 & $7.86^{* * *}$ & Yes \\
\hline & $\begin{array}{l}\text { H7: affective commitment } \rightarrow \text { loyalty } \\
\text { intention }\end{array}$ & + & 0.32 & $6.93^{* * *}$ & Yes \\
\hline & $\begin{array}{l}\text { H8: affective commitment } \rightarrow \text { advocacy } \\
\text { intention }\end{array}$ & + & 0.24 & $6.02^{* * *}$ & Yes \\
\hline & H9: affective commitment $\rightarrow$ wtpm & + & 0.01 & 0.27 & No \\
\hline & $\begin{array}{l}\text { H10: continuance commitment } \rightarrow \text { loyalty } \\
\text { intention }\end{array}$ & - & 0.02 & 0.49 & No \\
\hline & $\begin{array}{l}\text { H11: continuance commitment } \rightarrow \text { advo- } \\
\text { cacy intention }\end{array}$ & - & -0.01 & -0.34 & No \\
\hline & H12: continuance commitment $\rightarrow$ WTPM & - & 0.25 & $5.37^{* * *}$ & No \\
\hline & $\begin{array}{l}\text { H13: normative commitment } \rightarrow \text { loyalty } \\
\text { intention }\end{array}$ & + & 0.60 & $8.01^{* * *}$ & Yes \\
\hline & $\begin{array}{l}\text { H14: normative commitment } \rightarrow \text { advo- } \\
\text { cacy intention }\end{array}$ & + & 0.81 & $7.41^{* * *}$ & Yes \\
\hline & H15: normative commitment $\rightarrow$ WTPM & + & 0.53 & $6.86^{* * *}$ & Yes \\
\hline
\end{tabular}

${ }^{*} p<0.05(t>1.96) ;{ }^{* *} p<0.01(t>2.58) ; * * * p<0.001(t>3.29)$

2. QES The QES is a second-order factor model. First, environment quality is mainly measured by the graphic quality and the clear distribution; delivery quality is measured by attractiveness of selection, information quality, ease of use, and technical quality; outcome quality is measured by reliability, functional benefit, and emotional benefit. Second, the paths between first-order factor and second-order dimensions have a significantly positive impact. From Fig. 3 and Table 10, the testing results of the research hypotheses for the second-order dimensions show that all H2a, $\mathrm{H} 2 \mathrm{~b}$, and $\mathrm{H} 2 \mathrm{c}$ are empirically proven. (a) H2a: The testing result matches with the research results of Fullerton [21] and Yi and Gong [51]; that is, the higher environment quality provided by the shopping website, the the greater the impact on customers' feelings towards the service quality of the shopping website, since consumers believe that they have obtained better service quality. (b) H2b: The testing result matches the research results of Fullerton [21] and Yi and Gong [51]: Delivery quality is directly proportional to service quality. The better the delivery quality provided by 


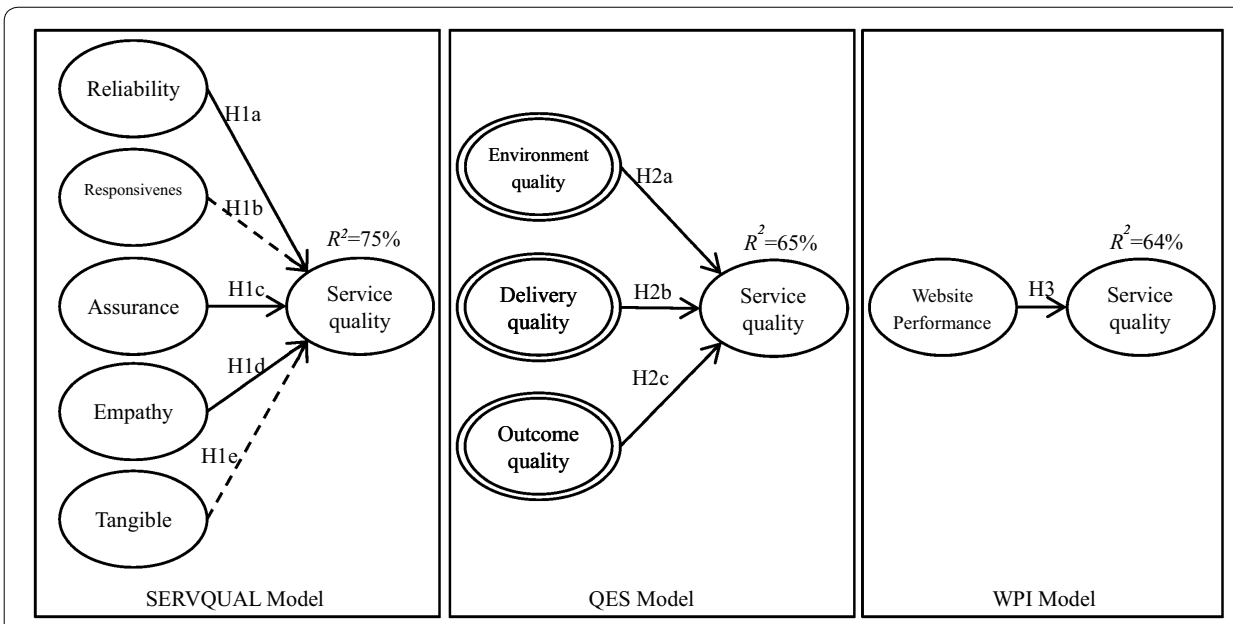

Note: solid lines indicate significant paths, and dashed lines indicate non-significant paths.

Fig. 3 Hypotheses testing results in the three models. Solid lines indicate significant paths, and dashed lines indicate non-significant paths

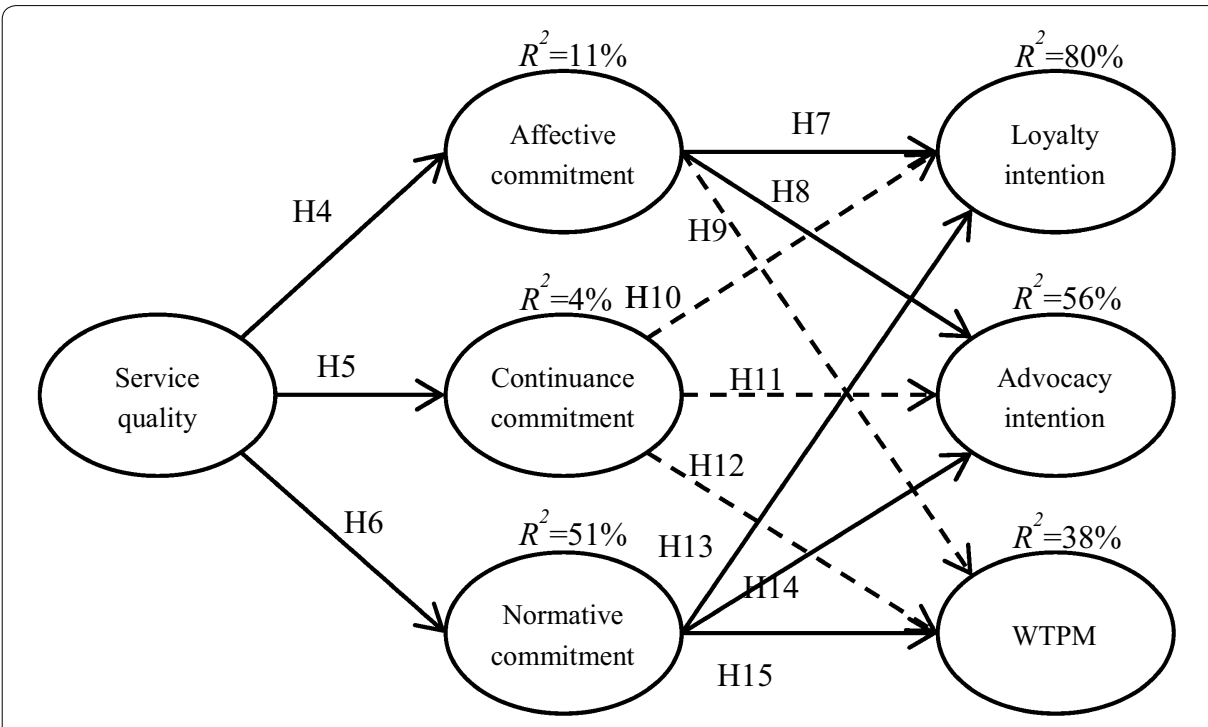

Note: solid lines indicate significant paths, and dashed lines indicate non-significant paths.

Fig. 4 Hypotheses testing results in the research framework. Solid lines indicate significant paths, and dashed lines indicate non-significant paths

the shopping website, the better the received service quality to the consumers. (c) H2c: The testing result also matches the research results of Fullerton [21] and Yi and Gong [51]: The better the outcome quality provided by the shopping website, the better the obtained service quality to the consumers.

3. WPI Similarly, website performance has a significant and positive impact on service quality from Fig. 3 and Table 10. The testing result has evidence: The better the website performance provided by the shopping website, the better the obtained service quality to the consumers. 


\section{Hypothesis verification of service quality to commitment}

It is also shown that H4, H5, and H6 are empirically proven from Fig. 4 and Table 10. (a) H4: Such a result matches with the research results of Fullerton [21] and Venetis and Ghauri [50]: When the website provides a better service quality, the affective commitment of the consumers towards the shopping website increases. (b) H5: Such a result also matches with the research results of Fullerton [21] and Venetis and Ghauri [50]: When the website provides a better service quality, the continuance commitment of the consumers towards the shopping website increases. (c) H6: The testing result is consistent with the research hypothesis in this study: When consumers believe that the service quality provided by the website is good, the normative commitment towards the shopping website significantly increases.

\section{Hypothesis verification of affective commitment to behavior intention}

Figure 4 and Table 10 show that, $\mathrm{H} 7$ and $\mathrm{H} 8$ are empirically proven but $\mathrm{H} 9$ is not supported. (a) H7: The testing result is consistent with the research results of Cater and Zabkar [9] and Davis-Sramek et al. [14]: When consumers have a higher affective commitment with the shopping website, the loyalty intention towards the shopping website significantly increases. (b) H8: The testing result is consistent with the research results of Fullerton [23, 24] and Lee et al. [38]: When consumers have a higher affective commitment with the shopping website, the advocacy intention towards the shopping website significantly increases. (c) H9: The reasonable reason might be that the consumers would use money in a rational way to meet the overall economic environment. Although the consumers prefer the shopping website to other bricks and mortar stores, they are not willing to pay higher price to purchase the product in the attitude of saving.

\section{Hypothesis verification of continuance commitment to behavior intention}

All the H10, H11, and H12 are not supported from the analytical results in Fig. 4 and Table 10. (a) H10: The reasonable explanation is the specific restriction of the shopping website. Consumers eventually decide to terminate the transaction relationship with the shopping website after a complete consideration to the costs and benefits as other shopping websites provide better profits. Restated, consumers may back to continue this relationship if the shopping website provides a better benefit. (b) H11: A reasonable reason may owe to the restriction, for which consumers cannot easily terminate the relationship with the shopping website, but they still believe that the website is the most beneficial one that is worth to work with after a complete thinking. However, the willingness to recommend the website to their friends is not strong. (c) H12: A possible reason may owe to the negative motivations, for which consumers have to maintain the continued relationship with the shopping website. The consumers are willing to accept a higher price when the continued benefits provided by the shopping website are still greater than other websites supported.

\section{Hypothesis verification of normative commitment to behavior intention}

It is shown that all H13, H14, and H15 are empirically proven from Fig. 4 and Table 10. (a) H13: The testing result is consistent with the research results of Bloemer and Odekerken-Schröder [7] and Hur et al. [31]. When consumers have a higher normative 
commitment with the shopping website, the loyalty intention towards the shopping website significantly increases. (b) H14: The testing result is consistent with Bloemer and Odekerken-Schröder's point of view [7]. When consumers have higher normative commitment with the shopping website, the advocacy intention towards the shopping website significantly increases. (c) H15: Also, the testing result is consistent with the research hypothesis: When the consumers have higher normative commitment with the shopping website, the continued interaction for WTPM towards the shopping website also significantly increases.

\section{Model comparison}

From Fig. 3, the $\mathrm{R}^{2}$ values of SERVQUAL, QES, and WPI are 75,65 , and $64 \%$ in the explanatory ability to service quality, respectively. Therefore, all the above three models have a good explanatory ability to service quality, and they are suitable to explain service quality as follows.

1. SERVQUAL has a higher explanatory ability; thus, it can be considered as the best measurement model because the measurement dimensions in this model include the entire service transmission process from the initial interaction with the customer service website design to the final fulfillment of the service. However, QES and WPI are only emphasized on the systemic functions of the website. Furthermore, the path coefficient of reliability dimension is greater than the others, meaning that it has the closest relationship to service quality.

2. QES is a second-order structure, including various first-order and second-order factors. This model is complex and has the second explanatory ability to service quality. However, the path coefficient of the environment quality is the smallest in Table 11.

3. The WPI has the lowest explanatory ability. Particularly, this model only has a single measuring dimension (i.e., the website performance) to service quality. This information represents that it has a high degree of simple explanatory ability, suitable for the evaluation of the website system performance and functions to service quality.

Generally, Table 11 shows aggregated the above analytical results in the three models.

\section{Conclusion and suggestion}

This study focuses on measuring the impact of the website service quality to the loyalty behaviors. Based on the above empirical results, a comprehensive discussion and conclusion is done, and the study result has the referenced value to academicians and practitioners for applications of online shipping field in the e-service.

\section{Conclusion}

In the recent decades, various shopping websites were established and aroused by the emerging prevalence of the Internet. If the shopping website cannot exist and emerge to the surface among the acute competitors, it will easily get overwhelmed by the wave of the online. Thus, there is an urgent necessity for the online shopping website to provide high service quality for the customers to experience a superior consumption in order to keep the customers in establishing a long-term mutual beneficial relationship with them. 
Table 11 Model comparison results

\begin{tabular}{lllll}
\hline Model & Hypothesis & Testing result & Path coefficient & $\mathbf{R}^{\mathbf{2}}$ \\
\hline SERVQUAL & Reliability $\rightarrow$ service quality & Support & 0.41 & $75 \%$ \\
& Responsiveness $\rightarrow$ service quality & & 0.01 & \\
& Assurance $\rightarrow$ service quality & Support & 0.28 \\
& Empathy $\rightarrow$ service quality & Support & 0.26 & \\
& Tangible $\rightarrow$ service quality & & -0.01 & $65 \%$ \\
QES & Environment quality $\rightarrow$ service quality & Support & 0.12 & \\
& Delivery quality $\rightarrow$ service quality & Support & 0.44 & $64 \%$ \\
& Outcome quality $\rightarrow$ service quality & Support & 0.36 & 0.80 \\
\hline
\end{tabular}

Among the measurement models of service quality, this study mainly applied SERVQUAL, QES, and WPI, which has been widely applied in other studies, to online shopping website field for finding the most appropriate measurement model. The empirical results are conclusively addressed in the following four key points.

1. SERVQUAL From Table 11, it is discovered that SERVQUAL has the best measurement model in this study, and its explanatory ability to the other dimensions achieves a high $75 \%$, meaning that the consumers care about the dimensions of reliability, assurance, and empathy provided by the shopping website. This information impliedly suggests that the management teams of the shopping website can develop or strengthen the service with the facets of reliability, assurance, and empathy for the customers. For example, regarding the reliability facet, the shopping website shall fulfill all promises to customers on time; customers therefore believe that the website is a reliable partner. By this way, consumers can sense the strength of service quality. As for the assurance dimension, the shopping website can strengthen the safety, privacy, and the payment certificate for the trading transactions, and consumers thus learn the professional operations and feel the improved service quality. In terms of empathy facet, the shopping website can provide customized system or recommended system to satisfy customers' particular needs in creating a good shopping experience.

2. QES The explanatory ability of the constituted second-order factor QES is $65 \%$. From the empirical result, it is discovered that environment quality, delivery quality, and outcome quality have a significant impact on service quality. Interestingly, environmental quality in QES has the least impact, which also echoes the analytical result of SERVQUAL. Regarding environment quality, both the models have the least impact on service quality, meaning that consumers put great attention to the overall process of the e-service transmission. In other words, the shopping website management operator allows consumers to have good interactions that are a good delivery quality, with the website during the e-service process. Delivery quality is composed by selection attractiveness, information quality, ease of use, and technical quality; thus, management operators of the website are suggested to focus on the following four aspects to offer a better e-service. (a) In terms of the selection attractiveness, the shopping website shall provide various and comprehensive ranges 
of products for consumers. (b) In information quality interface, the website shall timely update product information for providing all the necessary information to consumers. (c) As to ease of use, consumers shall easily use and guide the transaction procedure of the shopping website. (d) In technical quality, the shopping website shall have a stable transmission, high download speed, and constantly normal operation to the consumers.

3. WPI The explanatory ability of WPI is the lowest (64\%) among the three models, but particularly for that it only has one dimension to evaluating service quality; at the same time, its explanatory ability is similar to and only $1 \%$ less than QES, meaning that the impact on service quality is similar. Under the special context of the e-service environment, the website operator cannot provide a face-to-face contact service to the consumers but by through interaction platform; thus, the interface design becomes the core of the e-business. Importantly, product information quality, download speed, inquiry functions, and order system shall be carefully managed and optimized in order to improve service quality.

4. Commitment and behavioral intention Previously, some studies have emphasized on affective and continuance commitment rather than normative commitment; however, this study finds that such a stress in a prejudiced way may be a conservative bias. From the empirical results, it is proven that service quality has positive impact on affective, continuance, and normative commitment simultaneously. This information implies that management operators of online shopping business can establish customers' commitment through good service quality. Different types of commitments have distinct consequences over consumers' loyalty behavior. Based on this study, six key points are identified. (a) Affective commitment has positive effect on loyalty intention and advocacy intention, but negative effect on WTPM. (b) Continuance commitment has positive impact on loyalty intention and WTPM, but negative effect on advocacy intention. (c) Normative commitment has positive effect on loyalty intention, advocacy intention, and WTPM. (d) Interestingly and importantly, there exist differences when this study compared with the prior studies. Regarding the past studies, scholars believed that affective commitment is the key element to maintain the relationship with consumers, and management operators are thus recommended to maintain a long-term relationship with customers via affective commitment. However, this study finds that normative commitment has a greater impact degree on loyalty behaviors than affective commitment. (e) Particularly, this finding has further proven the viewpoint of Meyer and Allen [40]: They believed that social links and obligations are the emphasis in culturally collectivist countries where collective goals and interests take precedence over individual ones. Every person should consider other's benefit; thus, normative commitment highlights greater effect on the consumers' loyalty behavior than affective commitment. The study results echo with Meyer and Allen's point of view [40], particularly in terms of prices. (f) Affective commitment has no significant effect on WTPM, while normative commitment has a positive relationship with WTPM: The stronger the normative commitment, the greater the willingness to accept an increased price. Thus, this study recommends management operators of the shopping website to develop a strategy of good 
normative commitment for the consumers. This recommendation can positively increase the willingness of the consumers to visit and purchase in their website, to recommend to friends and acquaintances, and to have a high willing to accepting the increased price. In this strength, a long-term mutual-beneficial relationship with consumers is established, and the goal of sustainable operation for the shopping website is accordingly achieved.

Conclusively, the contribution of this study is to fill out the knowledge gap on differentiating "how" and "what" perspectives of SERVQUAL and QES and featuring their differences, which are scarce on literature review. Furthermore, it is also lack to assess the service quality of the e-business from the three perspectives of SERVQUAL, QES, and WPI simultaneously; particularly, this study completely finish.

\section{Research limitation and future research directions}

Although the study well performs and achieves a satisfied result, limitations or insufficiency in this study still exists due to the restricted time and resources. The following suggestions are determined for the subsequent researches.

1. Although this study expected to collect samples from wide age range, it was limited by the characteristics of questionnaire platform. Further studies can be done in different group targets for having representatives of a better result.

2. The impact of other variables, such as demographic variables, is not considered into different types of commitments and loyalty behaviors. Similarly, further researches can expand other variables rather than the variables in this study into the constructed theoretical structure.

3. This study is a cross-sectional research, which collects samples from a single time point. Thus, a longitudinal study can be done to expand the time range to having a further insight of service quality in the e-service fields or different application fields.

4. Regarding the research results, although some model fit indices information have not met the standard values in measurement model fit statistics, they still fall in an acceptable range. Notably, the analytical results in this study are helpful to feature the e-service of online website effectively. Furthermore, the unstandardized values of goodness-of-fit in the three models of this study also can be explored in future work.

Authors' contributions

The work was a result of substantive intellectual contributions to the content of this paper by each of the authors. All authors read and approved the final manuscript.

\section{Author details}

${ }^{1}$ Department of Information Management, National Yunlin University of Science and Technology, 123, University Road., Section 3, Douliou, Yunlin 640, Taiwan, ROC. ${ }^{2}$ Department of Information Management, Hwa Hsia University of Technology, 111, Gong Jhuan Road., Chung Ho District, New Taipei City 235, Taiwan, ROC.

\section{Acknowledgements}

We would like to thank the reviewers for their valuable comments.

Competing interests

The authors declare that they have no competing interests.

Received: 9 April 2015 Accepted: 22 December 2015

Published online: 10 May 2016 


\section{References}

1. Allen NJ, Meyer JP (1990) The measurement and antecedents of affective, continuance and normative commitment to the organization. J Occup Psychol 63(1):1-18

2. Anderson JC, Gerbing DW (1988) Structural equation modeling in practice: a review and recommended two-step approach. Psychol Bull 103(3):411-423

3. Bagozzi RP, Yi Y (1988) On the evaluation of structural equation models. J Acad Mark Sci 16(1):74-94

4. Bansal HS, Irving PG, Taylor SF (2004) A three-component model of customer to service providers. J Acad Mark Sci 32(3):234-250

5. Bendapudi N, Berry LL (1997) Customers' motivations for maintaining relationships with service providers. J Retail 73(1):15-37

6. Bhattacharya A, Wu W, Yang Z (2012) Quality of experience evaluation of voice communication: an affect-based approach. Human-Centric Comput Inform Sci 2(1):1-18

7. Bloemer J, Odekerken-Schröder G (2007) The psychological antecedents of enduring customer relationships: an empirical study in a bank setting. J Relat Mark 6(1):21-43

8. Brady MK, Cronin JJ Jr (2001) Some new thoughts on conceptualizing perceived service quality: a hierarchical approach. J Mark 65(3):34-49

9. Cater B, Zabkar V (2009) Antecedents and consequences of commitment in marketing research services: the client's perspective. Ind Mark Manage 38(7):785-797

10. Cho JE, Hu H (2009) The effect of service quality on trust and commitment varying across generations. Int J Consum Studies 33(4):468-476

11. Chuang HM, Chen YS (2015) Identifying the value co-creation behavior of virtual customer environments using a hybrid expert-based DANP model in the bicycle industry. Human-Centric Comput Inform Sci 5(1):1-31

12. Cialdini RB (2001) Harnessing the science of persuasion. Harvard Bus Rev 79(9):72-81

13. Cyr D, Bonanni C, Bowes J, Ilsever J (2005) Beyond trust: web site design preferences across cultures. J Global Inform Manag (JGIM) 13(4):25-54

14. Davis-Sramek B, Droge C, Mentzer JT, Myers MB (2009) Creating commitment and loyalty behavior among retailers: what are the roles of service quality and satisfaction? J Acad Mark Sci 37(4):440-454

15. Dean AM (1999) The applicability of SERVQUAL in different health care environments. Health Mark Q 16(3):1-21

16. Dickinger A, Stangl B (2013) Website performance and behavioral consequences: a formative measurement approach. J Bus Res 66(6):771-777

17. Fassnacht $M$, Koese I (2006) Quality of electronic services conceptualizing and testing a hierarchical model. J Serv Res 9(1):19-37

18. Fenglin L, Zaixin L (2008). Study on the quality of electronic services: conceptualizing and exploratory analysis. Paper presented at the 4th international conference of wireless communications, networking and mobile computing (WiCOM'08), 2008

19. Fornell C, Larcker DF (1981) Evaluating structural equation models with unobservable variables and measurement error. J Mark Res (JMR) 18(1):39-51

20. Fournier S, Dobscha S, Mick DG (1998) The premature death of relationship marketing. Harvard Bus Rev 76(1):42-51

21. Fullerton $\mathrm{G}$ (2005) The service quality-loyalty relationship in retail services: does commitment matter? J Retail Consum Serv 12(2):99-111

22. Fullerton $\mathrm{G}$ (2005) The impact of brand commitment on loyalty to retail service brands. Can J Adm Sci/Revue Canadienne des Sciences de l'Administration 22(2):97-110

23. Fullerton $\mathrm{G}$ (2005) How commitment both enables and undermines marketing relationships. Eur J Mark 39(11/12):1372-1388

24. Fullerton $\mathrm{G}$ (2011) Creating advocates: the roles of satisfaction, trust and commitment. J Retail Consum Serv 18(1):92-100

25. Geyskens I, Steenkamp J-BE, Scheer LK, Kumar N (1996) The effects of trust and interdependence on relationship commitment: a trans-Atlantic study. Int J Res Mark 13(4):303-317

26. Gounaris SP (2005) Trust and commitment influences on customer retention: insights from business-to-business services. J Bus Res 58(2):126-140

27. Gremler DD, Gwinner KP (2000) Customer-employee rapport in service relationships. J Serv Res 3(1):82-104

28. Hair JF, Anderson RE, Tatham RL, Black WC (1998) Multivariate analysis. Prentice Hall International, Englewood

29. Hill S, Provost F, Volinsky C (2006) Network-based marketing: identifying likely adopters via consumer networks. Stat Sci 21(2):256-276

30. Ho CW, Wang YB (2015) Re-purchase intentions and virtual customer relationships on social media brand community. Human-Centric Comput Inform Sci 5(1):1-16

31. Hur W-M, Park J, Kim M (2010) The role of commitment on the customer benefits-loyalty relationship in mobile service industry. Serv Ind J 30(14):2293-2309

32. Iwaarden JV, Wiele TVD, Ball L, Millen R (2003) Applying SERVQUAL to web sites: an exploratory study. Int J Qual Reliab Manag 20(8):919-935

33. Jeon MM (2009) Impact of perceived website service quality on customer e-loyalty on a lodging website. lowa State University, Ames

34. Johnson MS, Sivadas E, Garbarino E (2008) Customer satisfaction, perceived risk and affective commitment: an investigation of directions of influence. J Serv Mark 22(5):353-362

35. Jones T, Fox GL, Taylor SF, Fabrigar LR (2010) Service customer commitment and response. J Serv Mark 24(1):16-28

36. Kim H-W, Choi S, Kim K-H (2010) Examining online switching costs over search product and experience product contexts. PACIS 2010 Proceedings, p 61

37. Lee GG, Lin H-F (2005) Customer perceptions of e-service quality in online shopping. Int J Retail Distrib Manag 33(2):161-176

38. Lee K, Huang H, Hsu Y (2007) Trust, satisfaction and commitment on loyalty to international retail service brands. Asia Pac Manag Rev 12(3):161-169 
39. Ligas M, Chaudhuri A (2012) The moderating roles of shopper experience and store type on the relationship between perceived merchandise value and willingness to pay a higher price. J Retail Consum Serv 19(2):249-258

40. Meyer JP, Allen NJ (1997) Commitment in the workplace: theory, research, and application. Sage, Thousand Oaks

41. Narayandas D (1998) Measuring and managing the benefits of customer retention an empirical investigation. J Serv Res 1(2):108-128

42. Nunnally J (1978) Psychometric theory. McGraw-Hill series in psychology

43. Parasuraman A, ZeithamI VA, Berry LL (1985) A conceptual model of service quality and its implications for future research. J Mark 49(4):41-50

44. Parasuraman A, ZeithamI VA, Berry LL (1988) SERVQUAL: a multiple-item scale for measuring consumer perceptions of service quality. J Retail 64(2):12-40

45. Reichheld FF (2006) The microeconomics of customer relationships. MIT Sloan Manag Rev 47(2):73-78

46. Reichheld FF, Schefter P (2000) E-loyalty your secret weapon on the Web. Harvard Bus Rev 78(4):105-113

47. Saba T (2012) Implications of E-learning systems and self-efficiency on students outcomes: a model approach. Human-Centric Comput Inform Sci 2(1):1-11

48. Sharma N, Young L, Wilkinson I (2006) The commitment mix: dimensions of commitment in international trading relationships in India. J Int Mark 14(3):64-91

49. Srinivasan SS, Anderson R, Ponnavolu K (2002) Customer loyalty in e-commerce: an exploration of its antecedents and consequences. J Retail 78(1):41-50

50. Venetis KA, Ghauri PN (2004) Service quality and customer retention: building long-term relationships. Eur J Mark 38(11/12):1577-1598

51. Yi Y, Gong T (2008) The electronic service quality model: the moderating effect of customer self-efficacy. Psychol Mark 25(7):587-601

52. ZeithamI VA, Berry LL, Parasuraman A (1996) The behavioral consequences of service quality. J Mark 60(2):31-46

53. Zhou T, Lu Y, Wang B (2009) The relative importance of website design quality and service quality in determining consumers' online repurchase behavior. Inform Systems Manag 26(4):327-337

\section{Submit your manuscript to a SpringerOpen ${ }^{\circ}$ journal and benefit from:}

- Convenient online submission

- Rigorous peer review

- Immediate publication on acceptance

- Open access: articles freely available online

- High visibility within the field

- Retaining the copyright to your article

Submit your next manuscript at $\boldsymbol{\nabla}$ springeropen.com 